\title{
Monitoring of Deforestation Rate and Trend in Sabah between 1990 and 2008 Using Multitemporal Landsat Data
}

\author{
Razis Osman*, Mui-How Phua, Zia Yiing Ling and Kamlisa Uni Kamlun \\ School of International Tropical Forestry, Universiti Malaysia Sabah, Kota Kinabalu, Sabah 88400, Malaysia
}

\begin{abstract}
Deforestation is a major and very critical problem faced by many tropical countries including Malaysia. Sabah is the second largest state in Malaysia and its deforestation rate has been accelerating. This study was conducted to monitor the deforestation in Sabah in the last two decades with Landsat images of 1990, 2000 and 2008. Supervised classification with maximum likelihood algorithm was conducted using the Landsat data for monitoring deforestation. In total, between 1990 and 2008, Sabah lost half of its intact forest, or more than 1.85 million ha in less than two decades. Overall, the deforestation rate for all forest types combined for the last two decades was $1.6 \%$ per year. Deforestation seemed to be accelerating because the deforestation rate between 1990 and 2000 was $0.9 \%$ per year and it had increased to $2.7 \%$ per year between 2000 and 2008. The deforestation trend seemed to follow a negative exponential from 1990 to 2008. In contrast, the agricultural areas increased rapidly with a total of increment more than 1 million ha. This confirmed that agriculture especially establishment of commercial plantation was the major factor of deforestation in Sabah for the last two decades.
\end{abstract}

Key Words: Sabah, deforestation rate, deforestation trend, Landsat

\section{Introduction}

With a total of 255 million hectares, Southeast Asian rainforest is the second largest in the world (FAO 2011). It represents about $20 \%$ of the rainforests in the world but, deforestation rate in this region has been alarming (Geist and Lambin 2002). According to the Santilli et al. (2005), deforestation from Indonesian and Brazilian tropical forest alone is equavalent to about four-fifths of the annual reduction target in Kyoto Protocol. More than half of the earth's biodiversity has been threatened with extinction because the tropical forests are being destroyed at very critical rate (Sayer and Whitmore 1991; Laurance et al. 2001). Defore- station in the tropical region is also the source of massive emissions of green house gasses (Fearnside 2000; Laurence and Peres 2006). With the changes of global carbon cycle, socio-economic losses are enormous in long-term (Defries et al. 2002). Information about forest changes and forest resources are important in sustainable management of forest resources in a forest area (Kim et al. 2008).

Deforestation is the total removal of forest cover to less than $10 \%$ (Mayaux et al. 2005) while forest degradation can be characterized by reduction in proportion of canopy cover from closed to open or fragmented forest and also significant reduction in tree density (Karjalainen et al. 2003; Achard et al. 2004; DeFries et al. 2007). Deforestation can

Received: June 14, 2012. Revised: August 10, 2012. Accepted: August 10, 2012. 
be monitored using either a spectral change detection or post-classification comparison approach (Lunetta 1999). The spectral change detection approach examines the direction of physical changes between images. The post-classification comparison involves comparing land cover maps derived from multitemporal satellite images. Post-classification comparison is one of the widely practiced change detection method for monitoring deforestation, by conducting this approach; the changes to the classes detected more efficiently because it also gives the information about the new land cover types it become. The overall accuracy is equal to the product of the individual accuracies.

Borneo was one of the important regions in Southeast Asia that contained large tracts of tropical rainforests in 1990s (MacKinnon et al. 1996). In Sabah, much tropical forest has been destroyed by commercial logging for foreign currency earning since 1950s (Coutts 2006). However, driver of deforestation in Sabah has changed after 1980s to agricultural plantation (McMarrow and Talip 2001). Recent assessment of land cover change and deforestation in Borneo by Langner et al. (2007) was however limited in terms of temporal resolution (2002-2005) and spatial resolution (Moderate Resolution Imaging Spectroradiometer data). Nevertheless, the rates, causes and trends of deforestation have not been examined. We made use of the Landsat data to quantify the rate and trend of deforestation in the Malaysian state of Sabah, located at the northern part of Borneo Island, between 1990 and 2008.

\section{Materials and Methods}

\section{Study area}

Sabah (Fig. 1) is one of the thirteen states in the Federation of Malaysia. Sabah is the second largest state in Malaysia and situated at the northern part of Borneo, between $4^{\circ}$ and $7^{\circ}$ north of the equator. Climate of Sabah is generally influenced by the North-East Monsoon from November to February and the South-West Monsoon from May to August. The annual rainfall ranges between 1,700 $\mathrm{mm}$ and 5,100 mm. A large part of Sabah is hilly and mountainous, and it can be divided into four parts, which are western lowlands, Crocker range, the central uplands, and finally is the eastern lowlands (Sabah Forestry Department 2007).

\section{Data acquisition and pre-processing}

The Landsat program was first launched in 1972. Since then, seven Landsat satellites were launched and served global community until 2003 when malfunction of Scan Line Corrector (SLC) occurred onboard of Landsat7 ETM+. In this study, satellite data of 1990, 2000 and 2008 were acquired. Eight images of different path and row (Path/Row: 116/56; 116/57; 117/55; 117/56; 117/57; $118 / 55 ; 118 / 56 ; 118 / 57)$ were needed to produce a full image mosaic of Sabah of each year. In total, 16 images of Landsat TM were downloaded for the years 1990 and 2000. For 2008, we downloaded the SLC-OFF images of Landsat $\mathrm{ETM}+$. At least three images were acquired for filling the missing lines due to the SLC-OFF problem. The best quality image was placed at the top while the remaining images were used to fill the missing lines. These images were processed with the histogram matching method for matching the top-layer image prior to the missing line correction.

Being located in a tropical region, there are always cloud covers in almost all the Landsat images. Clouds affected only about $10 \%$ of Sabah for satellite images of 2000 and 2008 while $23 \%$ of the satellite images of 1990 were cloud-contaminated. Cloud masking was conducted prior to land cover classification.

Topographic maps (scale 1:50,000) were used as the reference and sources for "ground-truthing". The maps were georeferenced to the Universal Transverse Mercator with

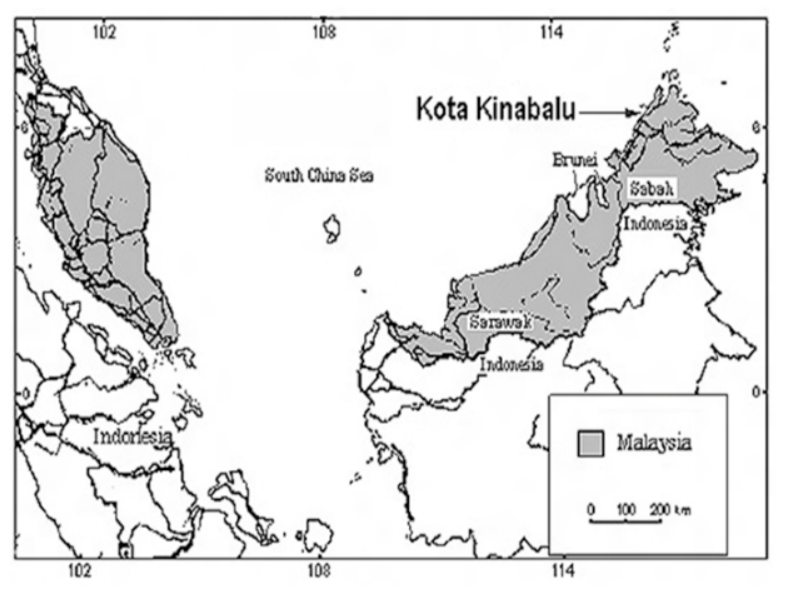

Fig. 1. Location of Malaysian state of Sabah in Borneo. 
the datum of World Geodetic System (WGS) 1984 and then used in rectification the satellite images. The georeference accuracy was within 1 pixel to ensure accurate overlay of land cover maps in the three years.

\section{Land cover classification}

Unlike unsupervisied classification, supervised classification uses a set of user-defined spectral signatures to classify an image. We defined 11 land cover classes (intact forest, degraded forest, peat swamp forest, mangrove, grassland, oil palm, rubber, bareland, water, cloud and shadows) based on visual interpretation of the images and knowledge about the study area. The spectral signatures were derived from training areas that were created interactively on the images. The topographic maps, field data and quick-look images of high-resolution images on Google Earth were used to delineate only training areas that appeared spectrally homogenous.

The maximum likelihood algorithm was employed in the classification. For the overlapping part between two adjacent scenes, we used the classification's result that was consistent to both scenes. The accuracy of the land cover classification was quantified based on the error matrix. The accuracy measures included overall, user's and producer's accuracies. The "ground truths", strictly speaking, were reference data from the topographic maps, Google Earth and field data. The images in each year were merged and stratified random sampling was used to generate points for accuracy assessment. Minimum number of points for each class was ten points and the total points were 204, 200, and 198 for years 1990, 2000 and 2008 respectively.

\section{Post-processing}

Some post-processing operations were carried out to improve the classification results (Fig. 2). This includes majority filtering $(3 \times 3)$ to reduce the 'salt-and-pepper' effect of the classification results. We also relabeled the land cover classification of 1990 to reduce the cloud cover of 1990 that significantly affected the intact forest in the central upland area. The cloud pixels of 1990 were relabeled as intact forest if it was classified as intact forest in both land cover classifications of 2000 and 2008. This has increased the intact forest of 1990 by nearly 300,000 ha or $9 \%$ of the intact forest in 1990 before the post-processing. The combined cloud cover in the three temporal years also reduced from $37 \%$ to less than one-third of the study area. With the range of accuracies and reduced area in mind, we interpreted and discussed the deforestation over the 28 years in terms of trend rather than of absolute numbers. Postclassification comparison of land cover change was conducted. We focussed on the area and percent of deforestation in two change periods (1990-2000 and 2000-2008. Trends of deforestation in the two change periods were derived from the land cover statistics.

\section{Results and Discussion}

The overall accuracies of the land cover classifications of 1990,2000 and 2008 were $80 \%, 74 \%$ and $75 \%$, respectively (Table 1-3). The overall accuracy of the land cover classification of 1990 was very good but the other two classifications were only satisfactory. Haze was the major problem in the Landsat images of 2000. This is evident in the inconsistent producer's and user's accuracies of bareland and water (Table 3). On the other hand, the overall accuracy of land cover classification of 2008 was affected by missing line correction (Table 3). Although histogram matching was conducted, differences between the temporal images were still relatively pronounced. The producer's and user's accuracies of the intact and degraded forests of

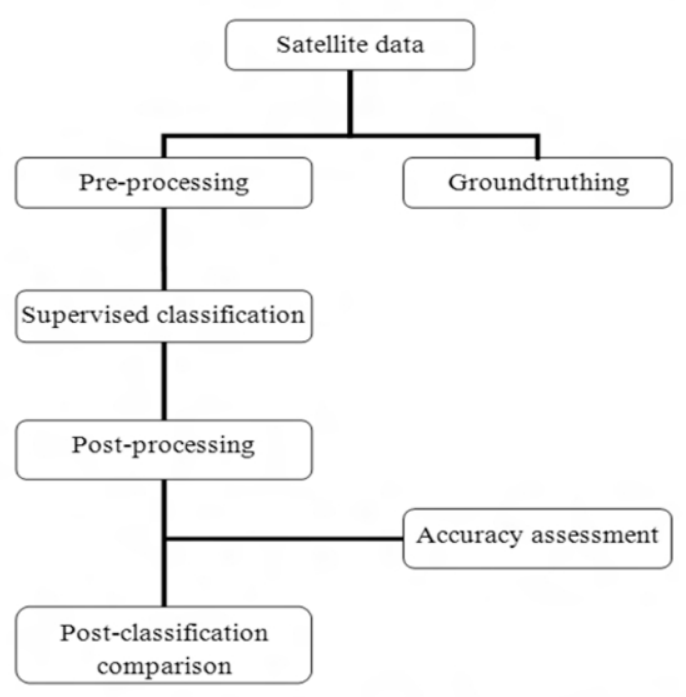

Fig. 2. Methodology flow chart. 
Table 1. Accuracy assessment of land cover classification of 1990

\begin{tabular}{lccccc}
\hline \multicolumn{1}{c}{ Class name } & Reference totals & Classified totals & Number correct & Producers accuracy & Users accuracy \\
\hline Intact forest & 34 & 39 & 29 & $85.29 \%$ & $74.36 \%$ \\
Degraded forest & 32 & 28 & 21 & $65.63 \%$ & $75.00 \%$ \\
Peat swamp & 12 & 20 & 12 & $100.00 \%$ & $60.00 \%$ \\
Mangrove & 30 & 21 & 20 & $66.67 \%$ & $95.24 \%$ \\
Grassland & 18 & 20 & 13 & $72.22 \%$ & $65.00 \%$ \\
Oil palm & 18 & 20 & 16 & $88.89 \%$ & $80.00 \%$ \\
Rubber & 14 & 10 & 10 & $71.43 \%$ & $100.00 \%$ \\
Bareland & 17 & 20 & 17 & $100.00 \%$ & $85.00 \%$ \\
Water & 29 & 26 & $89.66 \%$ & $100.00 \%$ \\
Totals & 204 & 204 & - & - \\
\hline
\end{tabular}

Overall classification accuracy $=80.39 \%$.

Table 2. Accuracy assessment of land cover classification of 2000

\begin{tabular}{lccccc}
\hline \multicolumn{1}{c}{ Class name } & Reference totals & Classified totals & Number correct & Producers accuracy & Users accuracy \\
\hline Intact forest & 26 & 30 & 21 & $80.77 \%$ & $70.00 \%$ \\
Degraded forest & 34 & 30 & 24 & $70.59 \%$ & $80.00 \%$ \\
Peat swamp & 5 & 10 & 4 & $80.00 \%$ & $40.00 \%$ \\
Mangrove & 29 & 17 & 16 & $55.17 \%$ & $94.12 \%$ \\
Grassland & 20 & 21 & 16 & $80.00 \%$ & $76.19 \%$ \\
Oil palm & 20 & 27 & 15 & $75.00 \%$ & $55.56 \%$ \\
Rubber & 16 & 15 & 11 & $68.75 \%$ & $73.33 \%$ \\
Bareland & 10 & 20 & 10 & $100.00 \%$ & $50.00 \%$ \\
Water & 40 & 30 & 147 & $75.00 \%$ & $100.00 \%$ \\
Totals & 200 & 200 & - & - \\
\hline
\end{tabular}

Overall classification accuracy $=73.50 \%$.

Table 3. Accuracy assessment of land cover classification of 2008

\begin{tabular}{lccccc}
\hline \multicolumn{1}{c}{ Class name } & Reference totals & Classified totals & Number correct & Producers accuracy & Users accuracy \\
\hline Intact forest & 22 & 37 & 19 & $86.36 \%$ & $51.35 \%$ \\
Degraded forest & 46 & 31 & 26 & $56.52 \%$ & $83.87 \%$ \\
Peat swamp & 9 & 10 & 8 & $88.89 \%$ & $80.00 \%$ \\
Mangroves & 20 & 16 & 15 & $75.00 \%$ & $93.75 \%$ \\
Grassland & 21 & 22 & 14 & $66.67 \%$ & $63.64 \%$ \\
Oil palm & 26 & 20 & 16 & $61.54 \%$ & $80.00 \%$ \\
Rubber & 7 & 12 & 6 & $85.71 \%$ & $50.00 \%$ \\
Bareland & 18 & 21 & 16 & $88.89 \%$ & $76.19 \%$ \\
Water & 29 & 29 & 149 & $100.00 \%$ & $100.00 \%$ \\
Totals & 198 & 198 & - & - \\
\hline
\end{tabular}

Overall classification accuracy $=75.25 \%$.

the land cover classification of 1990 ranged between $66 \%$ and $86 \%$. The values of both accuracy measures were in similar range for the land cover classification of 2000. The confusion between intact and degraded forests was relatively pronounced in the land cover classification of 2008 .

Fig. 3 show land cover classifications of Sabah from 


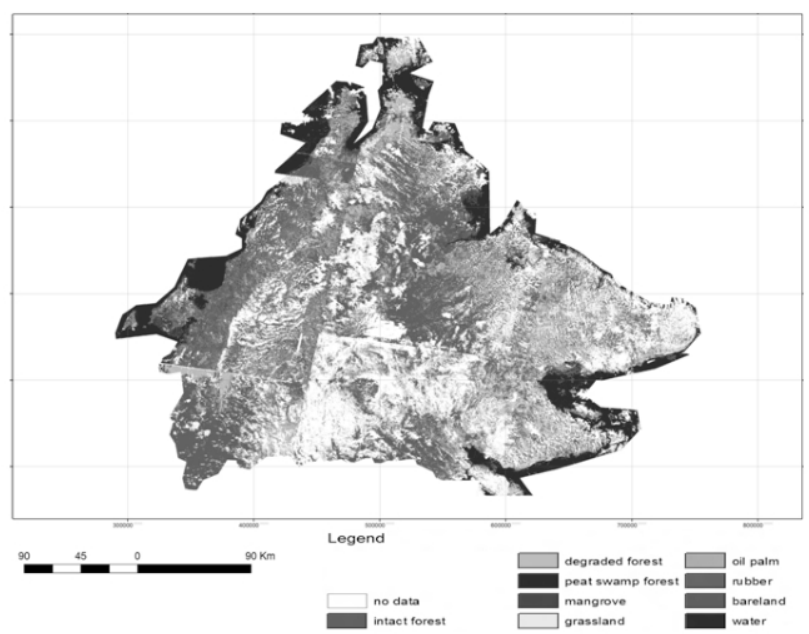

(A)

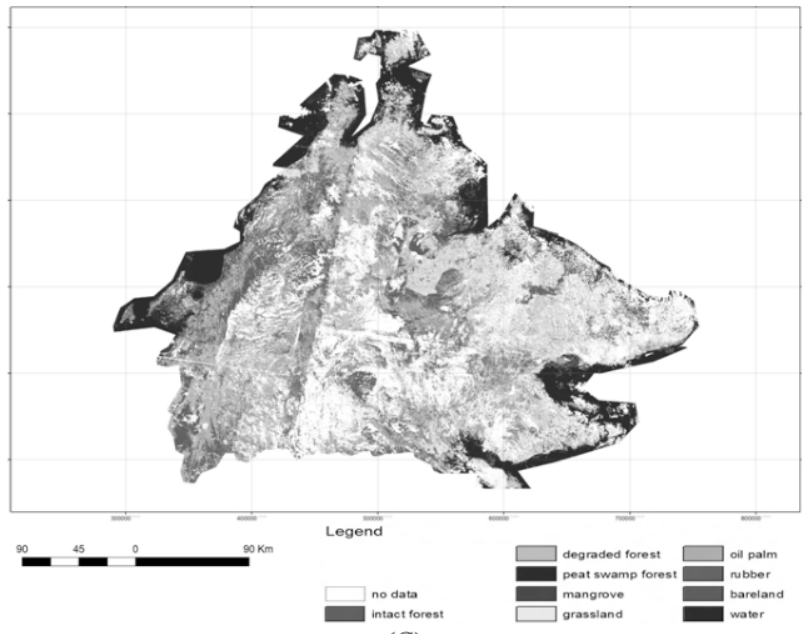

(C)

1990 to 2008. Between 1990 and 2000, Sabah lost about 1.16 million ha of intact forest (Fig. 4) or $3.3 \%$ per year. The intact forest had further shrunken almost 700,000 ha (Fig. 4 ) or $3.7 \%$ per year in the next eight years. In total, between 1990 and 2008, Sabah lost half of its intact forest, or more than 1.85 million ha in less than two decades.

The loss of intact forest between 1990 and 2000 was accompanied by the increase in degraded forest and (Fig. 3, 4). This indicates forest degradation because the intact forest that comprised of closed forest with high biomass and complex structure had become open forest with low biomass and simple structure. Almost $85 \%$ of the peat swamp forest in Sabah was lost between 1990 and 2000. While a significant part may be converted to oil palm plantation, the disastrous fires in 1997/1998 had destroyed large tracts of

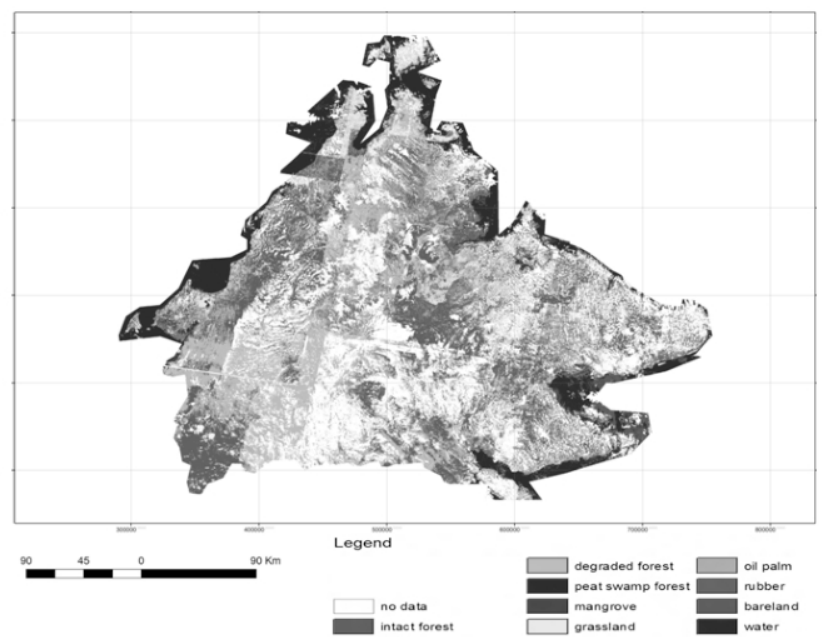

(B)

Fig. 3. (A) Land cover map 1990. (B) Land cover map 2000. (C) Land cover map 2008.

peat swamp forest in Sabah. In Klias Peninsular alone, about 11,000 ha were destroyed by the fires (Phua et al. 2007). That was why the peat swamp forest had increased about 30,000 ha or more than $40 \%$ per year between 2000 and 2008. Mangrove forest showed increment in both change periods. This may be due to the fact that most of the mangrove forest is under mangrove forest reserve in Sabah but some could be due to haze problem in the satellite images of 2009 .

Overall, the deforestation rate for all forest types combined for the last two decades was $1.6 \%$ per year. This is about 2.5 times higher than the deforestation rate in the neighboring state of Sarawak in almost the same period (1990-2009) (Tsuyuki et al. 2011). Deforestation seemed to be accelerating because the deforestation rate between 1990 


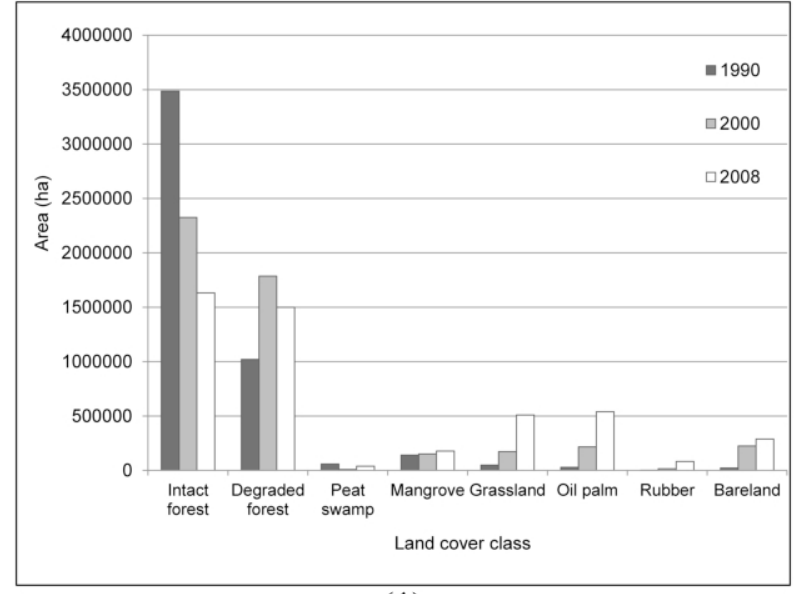

(A)

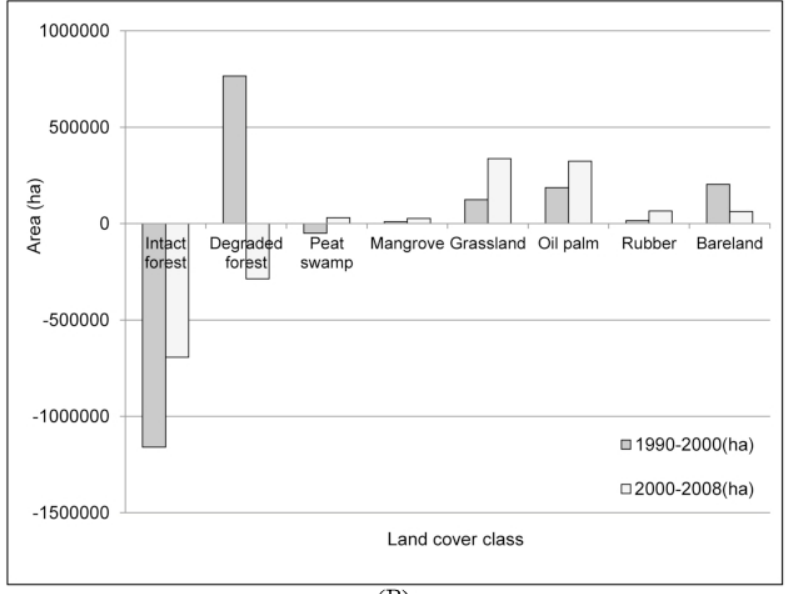

(B)

Fig. 4. (A) Land cover types between 1990 and 2008. (B) Land cover changes between 1990 and 2008.

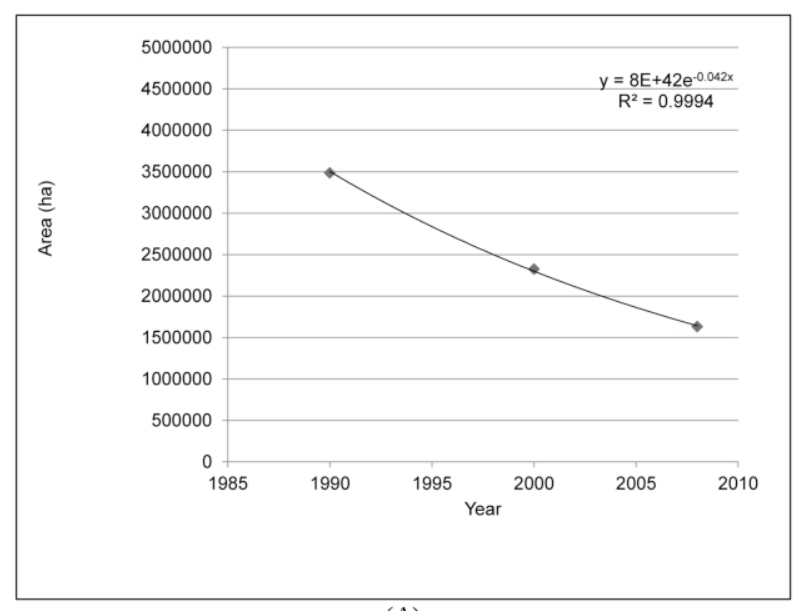

(A)

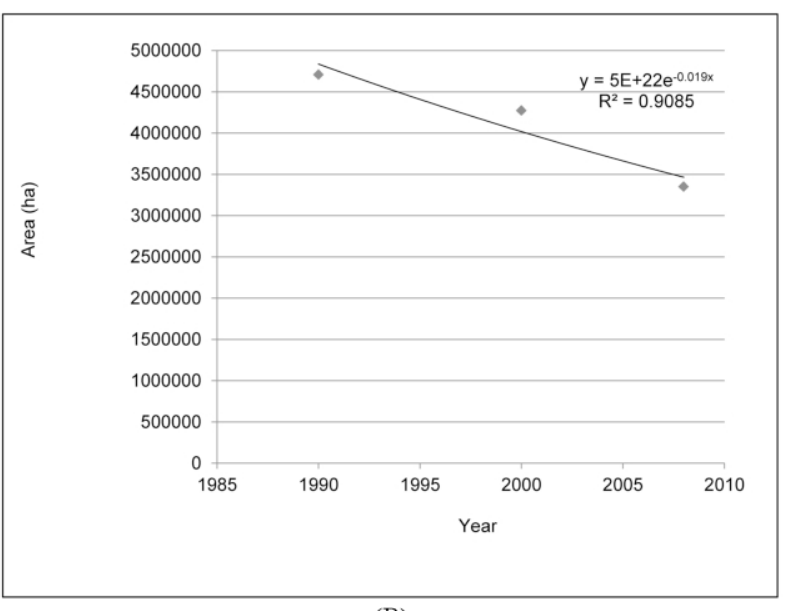

(B)

Fig. 5. (A) Deforestation trend of for intact forest. (B) Deforestation trend of for forest cover.

and 2000 was $0.9 \%$ per year and it had increased to $2.7 \%$ per year between 2000 and 2008.

Oil palm area had increased almost 200,000 ha or $65 \%$ per year between 1990 and 2000. Bareland grew more than 200,000 ha during the same period (Fig. 3, 4) at $92 \%$ per year; indicated accelerated new plantation establishment. After 2000, both intact and degraded forests decreased while agricultural lands (rubber and oil palm), had significantly increased (Fig. 4). Most of these bareland and grassland areas were at the initial stage of oil palm plantation establishment.

Commercial logging was an important source of export since 1950s in Sabah (Coutts 2006). However, plantation development especially for rubber, and then followed by oil palm in recent years, had replaced the commercial logging as the foreign currency earner in Sabah after 1980s (McMarrow and Talip 2001). Rubber plantation was discouraged by the sharp decrease in rubber price until after millennium, when the rubber price rebounded significantly. For instance, the selling price of SMR 20 in 2000 was RM $2.5 / \mathrm{kg}$ and became almost doubled in 2005 (Malaysian rubber board 2005). This may explain the increment of rubber area in the last two decades.

Based on a review of 55 studies that address the causes of deforestation in Asia concluded that deforestation in Asian forests was always followed by agriculture and plantation 
establishment (Geist and Lambin 2002). Sabah had a very fast increase in oil palm plantation in recent decades, and become the top in Malaysia in terms of oil palm plantation area (Malaysian Palm Oil Board [MPOB] 2008). Our study confirmed that the driver of deforestation in Sabah is similar to the major cause of deforestation in Asia; agriculture and plantations development. Langner et al. (2007) showed that deforestation in Borneo is strongly correlated to fire. In the Klias Peninsular of Sabah, large tracts of peat swamp forest was burned during the $1998 \mathrm{El} \mathrm{Niño} \mathrm{(Phua}$ et al. 2007) and $43 \%$ of the burned area was affected by fire again in 2003 (Phua et al. 2012). Fire has been a tool in traditional way of cultivation in Southeast Asia (MacKinnon et al. 1996). Culprits to the recent fire occurrence were shifting cultivators and plantations (Brookfield et al. 1995).

The land cover classifications of 1990, 2000 and 2008 made possible for developing the deforestation trend in the last two decades. Fig. 5A shows that the decreasing trend of intact forest in Sabah was well-fitted with a negative exponential function over time $\left(\mathrm{R}^{2}=0.999\right)$. Loss of forest cover also followed similar deforestation trend (Fig. 5B) whereby the forests were removed at an intensified rate and then slowed down because of fewer forests available for the forest-to-agricultural land conversion. A key issue in all project activities of Reducing Emissions from Deforestation and forest Degradation 'Plus' (REDD+) in developing countries, and avoided deforestation projects has been the development of baseline scenarios for avoided deforestation that reasonably represents the net emissions without the project (Brown 2007). If it was acceptable that the land cover classifications that represent $65 \%$ of Sabah land area as some kind of 'sampling', the trends provide 'very likely' baseline scenario of Sabah at subnational level.

\section{Conclusions}

With the fast depleting forest resources, forest carbon could be a realistic alternative for forestry industry in Sabah. In fact, the state's forestry department has already started testing monetary options from forest functions other than timber. To implement REDD+, avoided deforestation or related carbon mechanisms, the state needs to monitor deforestation as well as degradation at state level. With a large collection of satellite images, Landsat can offer historical land cover data for construction of deforestation trend toward establishing a baseline scenario. We examined the rates, trends and causes of deforestation in Sabah in the last two decades. The deforestation trends were clearly negative exponential and the prevailing cause was conversion of forests to agricultural plantations. Should there be no major change in forest policy and conservation strategy at state level, forest loss may be expected to continue until only legally gazetted forest areas such as forest reserves and parks are left.

\section{References}

Achard F, Eva HD, Mayaux P, Stibig HJ, Belward A. 2004. Improved estimates of net carbon emissions from land cover change in the tropics for the 1990s. Glob Biogeo Cyc 18: 1-11.

Brookfield H, Potter L, Byron Y. 1995. In Place of the Forest: Environmental and Socio-economic Transformation in Borneo and the Eastern Malay Peninsula. United Nations University, Tokyo.

Brown S, Hall M, Andrasko K, Ruiz F, Marzoli W, Guerrero G, Masera O, Dushku A, DeJong B, Cornell J. 2007. Baselines for land-use change in the tropics: application to avoided deforestation projects. Mitigation and Adaptation Strategies for Global Change 12: 1001-1026.

Coutts A. 2006. Deforestation of Malaysia: History, Causes and Consequences. Comparative Societies 1: 1-13.

DeFries R, Achard F, Brown S, Herold M, Murdiyarso D, Schlamadinger B, de Souza Jr C. 2007. Earthobservations for estimatinggreenhousegasemissions from deforestation in developingcountries. Environmental Science \& Policy 10: 385-394.

DeFries RS, Houghton RA, Hansen MC, Field CB, Skole D, Townshend J. 2002. Carbon emissions from tropical deforestation and regrowth based on satellite observations for the 1980s and 1990s. Proc Natl Acad Sci USA 99: 14256-14261.

Fearnside PM. 2000. Global warming and tropical land-use change: greenhouse gas emissions from biomass burning, decomposition and soils in forest conversion, shifting cultivation and secondary vegetation. Climatic Change 46: 115-158.

Food and Agriculture Organization (FAO). 2011. State of the World's Forests, Rome.

Geist HJ, Lambin EF. 2002. Proximate causes and underlying driving forces of tropical deforestation. Bioscience 52: 143-150.

Karjalainen T, Richards G, Hernandez T, Kainja S, Lawson G, Liu S, Prisley S. 2003. IPCC Report on Definitions and Methodological Options to Inventory Emissions from Direct Human-Induced Degradation of Forests and Devegetation of Other Vegetation Types. IPCC National Greenhouse Gas Inventories Programme (IPCC-NGGIP).

Kim DH, Nor DK, Jeong JH, Kim SH, Chung DJ. 2008. Forest 
resources of the Korea based on national forest inventory data. J For Sci 24: 159-164.

Langner A, Miettinen J, Siegert F. 2007. Land cover change 2002-2005 in Borneo and the role of fire derived from MODIS imagery, Glob. Change Biol 13: 2329-2340.

Laurance WF, Cochrane MA, Bergen S, Fearnside PM, Delamônica P, Barber C, D'Angelo S, Fernandes T. 2001. Environment. The future of the Brazilian Amazon. Science 291: 438-439.

Laurance WF, Peres CA. 2006. Emerging Threats to Tropical. Forests. University of Chicago Press, Chicago.

Lunetta RS. 1999. Applications, Project Formulation, and Analytical Approach. In: Remote Sensing Change Detection: Environmental Monitoring Methods and Applications (Lunetta RS, Elvidge CD, eds). Taylor and Francis Press, London, pp 1-19.

MacKinnon K, Hatta G, Halim H, Mangalik A. 1996. The Ecology of Kalimantan. The Ecology of Indonesia series Vol. III. Periplus Editions (HK) Ltd.

Malaysian Palm Oil Board (MPOB). 2008. Malaysian Oil Palm Statistics 2007. http://econ.mpob.gov.my. Accessed 16 Mar 2012.

Malaysian Rubber Board. 2005. Daily rubber price (2000-current data). http://www3.lgm.gov.my. Accessed 16 Mar 2012.

Mayaux P, Holmgren P, Achard F, Eva H, Stibig HJ, 2005.
Branthomme A. Tropical forest cover change in the 1990s and options for future monitoring. Philos Trans R Soc Lond B Biol Sci 360: 373-384.

McMorrow J, Talip MA. 2001. Decline of forest area in Sabah, Malaysia: Relationship to state policies, land code and land capability. Global Environ Change 11:217-230.

Phua MH, Tsuyuki S, Lee JS, Ghani M. 2012. Simultaneous detection of burned areas of multiple fires in the tropics using multisensor remote-sensing data. International J Rem Sens 33: $4312-4333$.

Phua MH, Tsuyuki S, Sasakawa H, Lee JS. 2007. Detection of burned peat swamp forest in a heterogeneous tropical landscape: A case study of Klias Peninsular, Sabah, Malaysia. Landsc Urb Plann 82: 103-116.

Sabah Forestry Department. 2007. Geography of Sabah-Resources. http://www.forest.sabah.gov.my. Accessed 16 Mar 2012.

Santilli M, Moutinho P, Schwartzman S, Nepstad D, Curran L, Nobre C. 2005. Tropical deforestation and the Kyoto Protocol: An editorial essay. Climatic Change 71: 267-276.

Sayer JA, Whitmore TC. 1991. Tropical Moist Forests: Destruction and Species Extinction. Biol Conserv 55: 199-213.

Tsuyuki S, Goh MH, Teo S, Kamlisa UK, Phua MH. 2011. Monitoring Deforestation in Sarawak, Malaysia using Multitemporal Landsat Data. Kanto For Res J 62: 87-90. 